\title{
Terminology and Concepts of Immigration Policy in Europe and in France
}

\section{[Terminologie a koncepty imigrační politiky v Evropě a ve Francii]}

\author{
Katerina Dvorakova
}

\section{DOI: 10.18355/XL.2016.09.01.2-23}

\begin{abstract}
Anotace
Veřejné diskuse $\mathrm{v}$ médiích na dnes aktuální téma imigrace ukazují na sémantickou nepřesnost, která obklopuje otázky spojené s migrací. Cílem tohoto textu je nejprve představit pojmy vztahující se $\mathrm{k}$ jednotlivým statutům migrujících osob, proceduře žádosti o azyl ve Francii i typům migrací. Poté představujeme milníky celoevropské i francouzské imigrační politiky a koncepty určující vztah mezi migrantem a přijímací zemí (assimilation - insertion - intégration), tak jak ve Francii procházely historickým vývojem. Připojen je francouzsko-český terminologický přehled na téma imigrace.

Klíčová slova

imigrace, azyl, integrace, Francie, Evropská unie
\end{abstract}

$\mathrm{Na}$ začátku 21. století se počet mezinárodních migrantů odhadoval na 175 milionů osob, v roce 2013 už to bylo 232 milionů. Podle evropské agentury Frontex se počet nelegálních migrantů do Evropské unie v roce 2014 téměř ztrojnásobil (přibližně 274000 osob) oproti roku 2013. Migrace přitom vzbuzuje znepokojení především $v$ přijímacích, většinou rozvinutých zemích, veřejné mínění vnímá příchod a usídlování migranti̊ s nedůvěrou a obavami. Nebezpečí terorismu spojovaného paušálně s náboženstvím islámu a strach $\mathrm{z}$ masivních imigračních vln $\mathrm{v}$ době ekonomické krize v Evropě vyvolávají nárůst preferencí populistických stran, jež volají po uzavření hranic. Nejinak je tomu i ve Francii, přestože je tato země dlouhodobě považována za zemi s velmi vstřícnou azylovou politikou a nečelí většímu př́ilivu imigrantů z třetích (neevropských) zemí poprvé.

Veřejné diskuse v českých i francouzských audiovizuálních médiích a tisku na toto dnes velmi živé téma ovšem ukazují na sémantickou nepřesnost, která obklopuje otázky spojené s migrací obecně. Naším cílem bude tedy nejprve v první části vymezit základní pojmy týkající se statusu osob dotčených fenoménem migrace: cizinec / imigrant / Francouz, tak jak je používají francouzské orgány pro své statistické účely. Zároveň musíme upřesnit základní lexikální pojmy z hlediska azylového práva ve Francii (žadatel o azyl / uprchlík / osoba neregulérně pobývající na území cizího státu), přičemž představíme i proceduru (ne)udělení statusu uprchlíka, tak jak je nyní ve Francii platná. Zároveň představíme základní typologii migrace z hlediska délky pobytu i její povahy.

Stále se stejnou optikou hloubkové analýzy lexika spojeného s tematikou imigrace se pak ve druhé a třetí části zaměříme na koncepty a migrační politiky, tak jak procházely historickým vývojem jak na francouzské, tak na celoevropské úrovni. Imigrační politika dnes není výhradní záležitostí jednotlivých členských států. Jednotný evropský akt a Schengenské dohody položily základy ke zrušení vnitřních hranic a volnému pohybu osob v evropském (schengenském) prostoru. $Z$ toho plyne i nutnost kontroly společných vnějších hranic a nutnost harmonizace norem ve vízové, azylové i přistěhovalecké politice na celoevropské úrovni. Vzhledem k tomu, že dnes francouzskou imigrační politiku nelze oddělovat od té společné celoevropské, představíme nejdůležitější milníky vývoje imigračních politik v Evropě a s nimi 
spojenou základní terminologii, poté se zaměříme na Francii, tradičně nahlíženou jako „zemi azylu“ či „zemi lidských práv“. Na základě historické analýzy azylové i přistěhovalecké politiky od 70. let 20. století do současnosti (vývoj od politiky asimilace po politiku integrace) i současných statistických údajů budeme zkoumat, zda je tento obraz opodstatněný a pravdivý, či nikoliv a jak se vyvíjel vztah mezi migranty a přijímací společností ve Francii.

Hloubková analýza lexika vymezujícího základní pojmy z hlediska statusu migrantů i azylového práva, ale i jednotlivé politické koncepty vycházející z evropské a především francouzské přistěhovalecké politiky nám na závěr umožní představit tematický česko-francouzský glosář rekapitulující toto lexikum.

\section{Upřesnění termínů: jednotlivé statuty a azylové právo ve Francii}

Evropské i francouzské statistické úřady dnes pro své účely výpočtu musí rozlišovat mezi jednotlivými podskupinami osob spojených s migrací a tvořících součást populace daného státu. Proto nyní upřesníme základní pojmy týkající se statusu těchto osob vzhledem $\mathrm{k}$ tomu, že jsou tyto pojmy ve veřejném či mediálním prostoru nepřesně použivány: např. ne každý cizinec je imigrant a naopak. Z hlediska měření populace je vhodné rozlišovat základní pojmy, jako „osoba francouzské státní příslušnosti“, „cizinec“ (étranger), přičemž je na místě vzít v úvahu i třetí termín „imigrant“ (immigré), který se s dvěma prvními vzájemně překrývá. Zároveň upřesníme principy a způsoby nabytí francouzské státní prŕslušnosti ve Francii.

Francouzem je každý člověk francouzské státní př́íslušnosti. Osoby francouzské státní př́íslušnosti tak mohou být narozeny jak ve Francii, tak v zahraničí. Je třeba rozlišovat pojmy vztahující se k získání francouzské státní příslušnosti: attribution a acquisition. Pojem attribution se uplatňuje u získání francouzské státní př́íslušnosti při narození (Français d'origine, de naissance), kdy rozlišujeme přidělení na základě státní př́slušnosti rodičů (attribution par filiation) při uplatnění droit du sang - jus sanguinis (alespoň jeden $\mathrm{z}$ rodičů dítěte je Francouz) a na základě narození dítěte ve Francii, kdy se v této zemi zároveň narodil alespoň jeden z rodičů (dvojí droit du sol, jus soli). Pojem acquisition se uplatňuje u cizinců, at' už imigrantů, kteří se naturalizací stali Francouzi (acquisition par décret de naturalisation), nebo nabyli francouzskou státní příslušnost sňatkem s Francouzem (acquisition par déclaration), nebo se narodili ve Francii a francouzskou státní příslušnost nabyli automaticky při dosažení plnoletosti (pokud od věku 11 let pobývali ve Francii po dobu alespoň pěti let) či dříve (na žádost rodičů již od 13 let věku) (acquisition de plein droit) (France Diplomatie, 2015).

Pojem „cizinec“ (étranger) je založený na hledisku státní příslušnosti: je to osoba, která „pobývá ve Francii a nemá francouzskou státní příslušnost, jelikož má jinou státní příslušnost (má výlučně tuto) nebo žádnou (osoby bez státní příslušnosti, apatrides). Osoby s francouzskou státní prŕslušností, které mají i jinou státní př́slušnost (i více), jsou ve Francii považovány za Francouze. Cizinec není nutně imigrant, jde i o osoby narozené ve Francii: často děti imigrantů, které nabudou francouzskou státní př́slušnost při dosažení plnoletosti. Statut „étranger“ je i proto samozřejmě potenciálně dočasný (cizinec se nabytím francouzské státní příslušnosti stává Francouzem) (INSEE, 2015a, viz také Tribalat, 1992).

S těmito dvěma oddělenými kategoriemi se částečně překrývá pojem imigrant

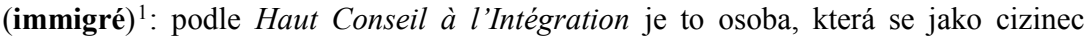

\footnotetext{
${ }^{1}$ Kromě termínu ,immigré” používaného pro stavy populace (stocks) se také často používá termín „migrant” či ,primo-arrivant” či „nouveau migrant” (nově 3
} 
narodila v zahraničí a sídlí ve Francii. Osoby narozené jako Francouzi v zahraničí a žijící ve Francii se tedy do této kategorie nepočítají. Cizinci a imigranti netvoří naprosto shodnou skupinu: imigrant není nutně cizinec a naopak: někteří cizinci se narodili ve Francii (zpravidla nezletilí). Na rozdíl od statusu cizince je status imigrant neměnný: i po nabytí francouzské státní př́slušnosti patří tyto osoby k populaci imigrantů. Migrační saldo (solde migratoire) představuje rozdíl mezi počtem přistěhovalých osob (immigrés) a vystěhovalých osob (émigrés): v roce 2014 činilo migrační saldo ve Francii 45000 osob (jde o výrazný pokles z důvodu zvětšujícího počtu emigrantů do zahraničí: např. v r. 2008 činilo saldo 66930 osob, v r. 2006 115025 osob). V roce 2011 (poslední dostupné údaje na webových stránkách INSEE) čítala Francie 5,6 milionu imigrantů ( $8,6 \%$ francouzské populace), z nichž 2,3 milionu jsou Francouzi ,par acquisition“ (viz výše) a 3,3 milionu osob jsou cizinci. Počet cizinců narozených ve Francii činil v roce 2011600000 osob. Celkových 3,9 milionu cizinců pobývajících ve Francii představuje $6 \%$ populace, což je i přes vzestup za poslední desetiletí méně než v letech 1931 a 1982, kdy šlo o $6,5 \%$. V roce 2013 získalo francouzskou státní příslušnost 97300 cizinců, z nichž více než polovina v rámci procedury naturalizace. K 31. prosinci 2012 vlastnilo povolení k pobytu 2,5 milionu státních příslušníků ze zemí mimo EU (70 \% z toho činí dlouhodobé povolení vydávané na 10 let a více). Hlavním motivem pro vydání povolení k pobytu je imigrace z rodinných důvodů (47\% vydaných povolení v roce 2013$)$, na druhém místě jde o studijní pobyty (29\%), migrační toky z třetích zemí z pracovních důvodů představují pouze něco málo přes $8 \%$, přestože za rok 2013 zaznamenaly nárůst o $10 \%$. V roce 2011 jsou v celkovém počtu imigrantů nejvíce zastoupeni Afričané (z nichž největší část zaujímají Alžířané s 13,2 \%), následovaní imigranty z Evropy (37,1 \%, nejvíce zastoupenou národností jsou Portugalci s 10,6\%), Asie (14,4 \%) a Ameriky (5,5\%). ${ }^{1}$ (V̌sechny údaje v tomto odstavci: INSEE, 2015b).

příchozí) pro označení migračních toků (vstupů na francouzské území za dané období) (Blum, Eberhard, 2014: 12).

${ }^{1}$ F. Cornuau (2008: 8-9) či M. Tribalat (2010) poukazují na nejednotnost statistických údajů týkajících se fenoménu imigrace ve Francii, která ztěžuje práci výzkumných pracovníkủ a demografů. Údaje neodrážejí vždy přesnou demografickou a sociologickou realitu z několika důvodů: neexistence jednotného systému sběru dat, zajišt'ovaného ve Francii několika aktéry s různým statistickým záměrem: ministerstvem vnitra, Národní agenturou pro př́jem cizinců a migrací (Agence nationale d'accueil des étrangers et des migrations, ANAEM), Francouzským úradem pro ochranu uprchlíků a osob bez státní příslušnosti (Office français pour la protection des réfugiés et des apatrides, OFPRA), národním statistickým úřadem INSEE, národním institutem pro demografická studia (Institut national des études démographiques, INED), Francouzským úřadem pro přistěhovalectví a integraci (Office français de l'immigration et de l'intégration, OFFI): napřr. ANAEM bere $\mathrm{v}$ úvahu pouze imigranty $\mathrm{z}$ třetích zemí, zatímco ministerstvo zahrnuje do svých údajů i státní příslušníky z Evropské unie; údaje slouží především správním, nikoliv vědeckým účelům, vstup na území neodpovídá nutně fyzickému vstupu, ale může být důsledkem i změny statusu (z neregulérně pobývajících osob na osoby „en situtation régulière"); statistická produkce velmi závisí na aktuální imigrační politice a legislativě: změny definic různých statusů $\mathrm{v}$ čase $\mathrm{v}$ závislosti na politických a legislativních změnách znemožňují koherentní a srovnatelné údaje v dlouhodobém měřítku; neexistují zdroje umožňující spočítat osoby neregulérně pobývající na území Francie, což vede často k velmi nepřesným odhadům. 
Poté, co jsme upřesnili základní pojmy spojené se statusem migrujících osob, je třeba také upřesnit pojmy vycházející z mezinárodního a francouzského azylového práva. V mediálním prostoru totiž např́klad často dochází $\mathrm{k}$ záměně pojmů „uprchlík“ a „žadatel o azyl“. Zároveň je zajímavé hlouběji představit mechanismy žádosti o azyl ve Francii: jaké instituce v tomto procesu zasahují a jaké ochrany mohou žadatelé o azyl v této zemi využít.

Uprchlík (réfugié) je osoba, která opustila zemi svého původu, protože se obává pronásledování pro rasovou, národnostní nebo náboženskou příslušnost, př́slušnost k určité sociální skupině či své politické názory, pro které se nechce nebo nemůže vrátit do státu, ve kterém má své státní občanství, nebo do státu svého posledního trvalého pobytu (viz také Lochak, 2013; Krulic, 2003). V jiné zemi, než je jeho, mu byla udělena azylová ochrana. Nejedná se o ekonomické migranty (migrant économique).

Žadatelem o azyl (demandeur d'asile) je člověk, který v jiné zemi, než zemi svého původu, žádá o udělení azylu nebo doplňkové/dočasné ochrany. I přestože právo na azyl vyplývá z Ženevské úmluvy z roku 1951 o postavení uprchlíků, spadá toto právo do kompetencí daného státu, který sám stanoví podmínky, které musí splňovat žadatel o azyl, aby získal status uprchlíka. Existuje několik druhů ochrany, kterých mohou žadatelé o azyl využít:

Žadatel o azyl ve Francii tak může např. být pod ochranou Vysokého komisaře OSN pro uprchlíky (Haut Commissariat des Nations Unis pour les réfugiés, HCR), založeného v roce 1950 pro zajištění ochrany a dodržování práv osob, které utíkají ze své země, aby unikly pronásledování. HCR má právo udělit status uprchlíka a využívá tří řešení: návrat do země původu, pokud to podmínky umožňují, integrace do země poskytující azyl, přesídlení do třetí země. Pokud se osoba pod ochranou HCR domnívá, že její ochrana $\mathrm{v}$ dané zemi není dostatečná, může se obrátit právě napřr. na Francii s žádostí o potvrzení statusu uprchlíka. Pokud ta uzná, že dané osobě byl statut uprchlíka HCR udělen oprávněně, může žadatel ve Francii zůstat.

Francie také poskytuje konvenční, neboli politický azyl (asile conventionnel, asile politique), který vychází $\mathrm{z}$ výše zmiňované Ženevské úmluvy. Je třeba splnit následující podmínky: daná osoba byla předmětem osobního, prokázaného a aktuálního pronásledování, nebo se obává, že jím bude, a to z jasně stanovených důvodů (rasový, náboženský, národnostní motiv, př́slušnost k nějaké sociální skupině, politické přesvědčení, s vyloučením jakéhokoliv jiného motivu). Žadatel také musel opustit svou zemi, která nemůže svého státního př́slušníka ochránit nebo je sama původcem pronásledování.

Dalším př́ípadem je azyl konstituční, či ústavní (asile constitutionnel), který vychází ze čtvrtého pododstavce preambule francouzské Ústavy z roku 1946 a může být udělen tomu, kdo je reálně utlačován a pronásledován (tedy na rozdíl od konvenčního azylu nestačí, že má z pronásledování obavy), a to výhradně v rámci boje za svobodu, přičemž není stanovena přesná definice tohoto boje. Z judikatury Národního soudu azylového práva (viz níže) vyplývá, že za takový byl v minulosti považován např. boj na podporu práv žen v Afghánistánu či veřejné angažování na podporu sociálních programů a boj proti obchodu s drogami v Kolumbii. Na rozdíl od Ženevské úmluvy, která po žadateli nevyžaduje skutečnou aktivitu či účast v boji (stačí, aby byl obětí pronásledování), francouzská Ústava reálnou aktivitu vyžaduje.

Jiným typem azylové ochrany je doplňková ochrana (protection subsidiaire, dřive územní azyl, asile territorial, zrušený ve Francii v roce 2003 a opírající se o čl. 3 Evropské úmluvy o ochraně lidských práv a základních svobod), kterou mohou využívat osoby nespadající do kategorií výše zmíněných ochran a které jsou ve své zemi vystaveny závažnému nebezpečí: trest smrti, mučení či degradující a nelidské tresty a zacházení, vážné, př́ímé a individuální ohrožení života na základě vnitřního či mezinárodního ozbrojeného konfliktu. Zároveň tyto osoby ale nesplňují podmínky pro 
to, aby jim byl přidělen status uprchlíka, a v př́ípadě, že daná situace $\mathrm{v}$ zemi původu ustane, je doplňková ochrana ukončena.

Ve Francii i EU existuje i dočasná ochrana (protection temporaire), která byla ustanovena na základě pohybu migrantů vzešlého z války v Kosovu v roce 1999, $\mathrm{s}$ cílem okamžitě a dočasně (doba ochrany 1 rok, prodloužitelná maximálně na 3 roky) ochránit migranty v rámci (iminentního) masivního prŕlivu vysídlenců z třetí země. Nebyla však nikdy uplatněna.

V rámci zpř́ísnění azylové politiky ve Francii a ztíženého přístupu ke statusu uprchlíka lze od roku 2003 kromě klasických motivů jako je nedostatečná průkaznost pronásledování či nepřesnost výpovědi uplatňovat pro zamítnutí žádostí o azyl i tři nová zdůvodnění: vnitřní azyl (asile interne: žadatel má př́stup k ochraně na území své země původu, či alespoň její části, a neexistují obavy o jeho pronásledování na tomto území); existence mezinárodních a regionálních organizací a instancí (agents de protection), které mohou žadateli poskytnout ochranu na území jeho státu původu, pokud tento tak nečiní; konečně bezpečné země původu (pays d'origine sûrs), v nichž je státní moc způsobilá zajistit dodržování lidských práv a právních předpisů, na základě ratifikace mezinárodních smluv o lidských právech a základních svobodách. Každý rok (naposledy na konci roku 2014) dochází ve Francii k revizi rozšíření tohoto seznamu bezpečných zemí. Podobně je tomu v př́ípadě bezpečné třetí země (pays tiers sûr), tedy jiné země, než je stát, jehož je cizinec státním občanem, ve které cizinec pobýval před vstupem na území, a do které se může tento cizinec vrátit a požádat o udělení postavení uprchlíka podle mezinárodní smlouvy, aniž by byl vystaven pronásledování, mučení, nelidskému nebo ponižujícímu zacházení nebo trestu. Přichází-li žadatel o udělení statusu uprchlíka z těchto dvou skupin zemí, lze také jejich žádost zamítnout jako nedůvodnou.

Současná evropská imigrační krize a hromadný př́liv migrantů ze třetích zemí nás nutí si položit otázku procedury podání žádosti o azyl ve Francii, kterou musí každý žadatel podstoupit, včetně současných časových lhůt vázajících se k jednotlivým etapám. Ve Francii disponují imigranti po svém příchodu 21denní lhůtou na to, aby podali žádost o azyl na Office français de protection des réfugiés et des apatrides (OFPRA), který rozhoduje o (ne)udělení statusu uprchlíka či doplňkové ochrany a zároveň poskytuje právní a administrativní ochranu uprchlíkům. V roce 2014 průměrná doba vyřízení žádosti činila 205 dnů (z 64811 žádostí 13859 z nich se týkalo nezletilých osob - jich 30000 zůstalo nevyř́zených). Pro dobu před vyřizením této žádosti dostává imigrant dočasné povolení k pobytu (autorisation de séjour provisoire), může požádat o ubytování ve středisku přijetí pro žadatele o azyl (Centre d'accueil de demandeurs d'asile) nebo v jiných asociacích a pokud nemá žádné finanční zdroje, může požádat o dočasný čekací příspěvek (allocation temporaire d'attente, 340 eur/měsíc). Žadatel se proti rozhodnutí může do jednoho měsíce odvolat k nezávislému soudu Cour nationale du droit d'asile (CNDA), který je ovšem ještě více zaneprázdněn: čekací lhůta se může prodloužit na 2 roky i déle. Pokud i CNDA žádost odmítne, migrant (débouté du droit d'asile) je nucen opustit francouzské území (obligation de quitter le territoire français, OQTF), opět se ovšem lze odvolat ke správnímu soudu (Tribunal administratif). V současnosti prochází legislativním procesem reforma francouzského azylového řízení, která předpokládá zkrácení jednotlivých procedur.

Cizím státním př́íslušníkem neoprávněně pobývajícím na území jiného státu než země jeho původu (étranger / migrant en situation irrégulière, ,sans-papier") je člověk bez platného povolení k pobytu v dané zemi (turistické, studentské vízum, pobytová karta atd.) - platnost daného povolení mu vypršela nebo vstoupil na území daného státu bez tohoto povolení. Migranti v tomto posledním př́ípadě, pro které je zpravidla těžké vzhledem $\mathrm{k}$ situaci $\mathrm{v}$ jejich zemích původu obdržet vízum, jsou ovšem 
pod zákonnou ochranou během doby projednávání jejich žádosti o azyl. Termíny jako „nelegální migrant“ (migrant illégal, clandestin) jsou proto (ve francouzštině) nahrazovány výše zmíněným „migrant en situation irrégulière“, jelikož dané osoby jsou pod specifickou ochranou národního i mezinárodního práva, kterou přestupem hranic neztratily a která jim naopak uděluje různá práva, jako např. právo požádat o azyl, právo na spravedlivý soudní proces atd.

Představili jsme jednotlivé statusy migrujících osob i základní typy ochrany a instituce spojené s azylovou problematikou a procedurou žádosti o azyl ve Francii. Zbývá rozlišit jednotlivé typy migrací pro lepší orientaci v tématice imigrace obecně.

$\mathrm{Z}$ hlediska typologie imigrace existuje několik rozlišovacích kritérií (Cornuau, Dunezat, 2008: 338). Podle délky pobytu rozlišujeme na základě statistických doporučení OSN imigraci dlouhodobého či trvalého charakteru (immigration à caractère permanent, minimálně jeden rok) a imigraci dočasnou (immigration à caractère temporaire, do jednoho roku). Vymezení dlouhodobého charakteru u prvního typu je ovšem široké, nebot' do této kategorie patří ne vždy prodloužená jednoletá povolení k pobytu (titre / permis de séjour) i desetileté prodloužitelné pobytové karty pro dlouhodobé rezidenty (carte de résident) a naopak, do druhé, „dočasné“ kategorie spadají migranti, kteří mohou pobývat ve Francii několik let (studenti, žadatelé o azyl atd). Ze statistického hlediska je třeba vyzdvihnout, že instituty jako je Institut national d'études démographiques (INED) ve Francii berou pro statistické účely $\mathrm{v}$ oblasti imigrace $\mathrm{v}$ potaz pouze imigraci dlouhodobou.

Dalším rozlišovacím kritériem je motiv imigrace (Cornuau, Dunezat, 2008: 338). Rozlišujeme tak nap̌r. imigraci za prací (immigration professionnelle): ve Francii existují pobytové karty pro vybrané kategorie pracovníků: mentions „compétence et talents“ (viz níže), „profession artistique“ - pro umělecká povolání, „scientifique“ pro védecké pracovníky, „salarié“ - zaměstnanci, „commerçant“ - obchodníci). Svou roli hraje opět délka pobytu (stážisté, studenti, sezónní pracovníci - travailleurs saisonniers, kteří mají většinou maximálně šestiměsíční povolení k pobytu, zatímco pracovníci se smlouvou na dobu neurčitou - travailleurs permanents - mají jednoroční obnovitelnou pobytovou kartu).

Jiným typem migrace $\mathrm{z}$ tohoto hlediska je migrace $\mathrm{z}$ rodinných důvodů (migration pour raisons familiales), do které spadají př́chody celých rodin či jejich blízkých: $v$ rámci sloučení rodiny (regroupement familial) mohou přicházet rodinní př́slušníci cizinců pobývajících ve Francii, spadají sem i imigranti, kteři přicházejí za členem rodiny, který má francouzskou státní př́slušnost nebo status uprchlíka. Tyto osoby mohou obdržet bud' jednoletou pobytovou kartu „,vie privée et familiale“ či desetiletou kartu pro rezidenty.

Třetím typem je imigrace z politických důvodů (immigration politique), které využívají žadatelé o azyl (procedura viz výše). Pokud je žadateli přiznán status uprchlíka, obdrží desetiletou kartu pro rezidenty a spadá do dlouhodobé imigrace, zatímco žadatelé o azyl spadají do kategorie imigrace krátkodobé / dočasné. V př́padě doplňkové ochrany (protection subsidiaire) je vystaveno pouze jednoleté povolení k pobytu.

Po tomto základním terminologickém přehledu vymezujícím statusy migrantů, motivy a aktéry žádosti o azyl ve Francii i typologii migrace obecně bude zajímavé se hlouběji zaměřit na terminologii spojenou $\mathrm{s}$ přistěhovaleckými politikami a koncepcemi vnímání osoby imigranta ve Francii tak, jak se vyvíjely v čase od historického zlomu, kterým byly ropné šoky a ekonomická krize v 70. letech minulého století, po současnost. Vzhledem k postupující komunitarizaci evropské přistěhovalecké politiky ( $\mathrm{v}$ původně mezivládní agendě se dnes uplatňuje supranacionální př́stup, od kterého jsou odvislé jednotlivé přistěhovalecké politiky členských států) je ovšem nejprve nutné vymezit základní etapy vývoje společné 
evropské imigrační politiky, tak jak se utvářela od podpisu Jednotného evropského aktu, a s nimi související relevantní terminologii.

\section{Situace v Evropě}

Poté, co byla Evropa po dlouhá staletí emigračním regionem, ze kterého lidé odjížděli směrem k zemím Nového světa či evropským koloniím, je dnes jednou z prvních imigračních destinací na světě. Dnes čelí obrovské imigrační krizi, nutnosti regulovat imigrační toky a modality soužití i veřejnému mínění zasaženému strachem z bezpečnostních otázek. Do Evropy dnes mírí stovky tisíc žadatelů o azyl z politických, rasových a náboženských důvodů i ekonomických migrantů. Největší pozornost se dnes zaměřuje na Středomoří, které představuje jednu z nejvíce využívaných a zároveň nejnebezpečnějších cest $\mathrm{k}$ branám Evropy.

Světové migrační toky, které se dotýkají i Evropy, jsou v posledních dvaceti letech podle Catherine Withol de Wendenové (2008: 2 a 2009: 43 - 53) výsledkem několika souběžných faktorů: země jižní a východní Evropy se změnily z emigračních zemí na imigrační a/nebo tranzitní země (pays de transit); všeobecné zavedení pasů a tedy práva opustit svou zemi, přičemž se zároveň zpř́ísňovala vízová politika bohatých zemí; dosud nezažitý obrovský nárůst žádostí o azyl v 90. letech minulého století, kdy se Evropa stala upřednostňovanou destinací před Spojenými státy a Kanadou z oblastí afrických Velkých jezer, balkánských zemí, Blízkého a Středního Východu, Karibiku; aktivace legálních i ilegálních nadnárodních sítí, které uvedly do pohybu řetězové migrace (migration en chaîne - migranti mají v místě destinace své příbuzné či přátele, kteří jsou ochotni jim poskytnout pomoc); rozvoj kyvadlových migrací (migration pendulaire), kdy migranti odjíždějí na kratší dobu s vidinou návratu (především východní / západní Evropa díky volnému pohybu osob); zeměpisná blízkost spojená $\mathrm{s}$ všeobecným zlevňováním především letecké dopravy $\mathrm{i}$ s obrazem Evropy šířeným médii v zemích původu a s všeobecnou vyšší informovaností o destinacích v éře internetu, s lokálními trhy zásobovanými evropskými výrobky a s převody finančních prostředků imigrantů směrem k zemím původu - to vše zvyšuje chut' po Evropě.

\subsection{Společná imigrační politika?}

Utváření společné evropské imigrační politiky (především vízové a azylové, přistěhovalecká politika a legislativa upravující integraci dlouhodobých migrantů zůstává v kompetenci členských států) probíhalo a probíhá v několika etapách a není cílem tohoto článku podrobně představit veškerou evropskou legislativu v této oblasti. Než představíme vývoj imigrační politiky ve Francii, omezíme se zde na hlavní momenty utvářející evropský legislativní prostor v oblasti imigrace (De Wenden, 2008: 7-9). Zásadním zlomem bylo přijetí Jednotného evropského aktu (Acte unique européen) v roce 1985, který ustanovil volný pohyb osob (nikoliv už jen pracovníků), a podpis Schengenské dohody (accord de Schengen) v roce 1985 o postupném rušení kontrol na vnitřních hranicích a zároveň zpřísnění kontrol na hranicích vnějších a o boji proti ilegální imigraci. Schengenský prostor dnes tvoří 26 států, dohoda byla doplněna v roce 1990 Úmluvou k provedení Schengenské dohody (Convention d'application de l'accord de Schengen), z níž vyšla následující opatření a dále se utvářela společná imigrační politika:

- přijetí jednotného víza (visa unique) s maximální dobou platnosti 3 měsíců, povinného pro občany třetích zemí;

- volný pohyb osob v rámci evropského prostoru a posílení vnějších hranic díky postupnému prristupování dalších zemí k schengenskému systému a solidaritě evropských zemí uvnitř a vně schengenského prostoru při kontrole vnějších hranic: od roku 1991 jsou podepisovány readmisní dohody (accords de réadmission) se 
sousedními zeměmi, které upravují vzájemné předávání občanů jednoho státu, kteří neoprávněně vstoupili nebo neoprávněně pobývají na území státu druhého, do země jejich původu;

- přijetí kontrolního Schengenského informačního systému (système d'information Schengen I a II) pro vytvoření společné databáze hledaných, pohřešovaných i nežádoucích osob (např. jim byla zamítnuta žádost o azyl, les déboutés du droit d'asile), kterým jsou evropské státy povinny odmítnout právo na pobyt;

- v rámci společné azylové politiky přijetí Dublinské úmluvy I (1990), II (2003) a III (2013) (accords de Dublin) určující, který stát je příslušný k posuzování žádosti o azyl. Mezi kritérii např́íklad figurují rodinné vazby žadatele o azyl, skutečnost, že žadatel je držitelem víza či povolení $\mathrm{k}$ pobytu $\mathrm{v}$ některém členském státě, nebo vstoupil na území členských států neoprávněně a v neposlední řadě i skutečnost, že poprvé již v některém členském státě o azyl požádal. Tento stát musí uprchlíka přijmout a provést $s$ ním azylové řízení, případně se postarat o jeho návrat do země původu nebo do jiné země, která se $\mathrm{k}$ jeho přijetí zavázala např́iklad $\mathrm{v}$ rámci readmisních dohod;

- přijetí Amsterdamské smlouvy v roce 1997, novelizující zakládací smlouvu ES, obsahující Hlavu IV. s názvem: Vízová, azylová a přistěhovalecká politika a jiné politiky týkajici se volného pohybu osob, představovalo významný mezník ve vývoji migrační politiky: Schengenské dohody byly přeneseny do právního rámce EU a část třetího pilíře justice a vnitra byla převedena do prvního pilíře, včetně otázek azylu a migrace. Ty se tedy staly součástí komunitárního práva a nadále mohly být upravovány - na rozdíl od Maastrichtské smlouvy - právně závaznými nástroji na úrovni ES, zejména směrnicemi a nařízeními. Na základě aktuální Lisabonské smlouvy se rozhoduje řádným legislativním postupem (procédure législative ordinaire), kdy mají Evropský parlament a Rada rovnocenné postavení při schvalování právních aktů a návrhy Komise si vyžadují souhlas kvalifikované většiny (vote à la majorité qualifiée) zemí EU. Protokol 29, zvaný též Aznarův protokol, připojený k Amsterodamské smlouvě, zavádí, že se všechny členské státy navzájem považují za bezpečné země (pays sûrs), žádosti o azyl z těchto zemí jsou proto považovány za bezpředmětné;

- iniciativy pro omezení migračních toků pomocí externalizace azylové politiky (Kabwe-Segatti, 2009; Boswell, 2003) a boj proti nedovolené migraci. S postupným utvářením Schengenského prostoru Evropa postupně zaváděla opatření a nástroje ztěžující podmínky vstupu do tohoto prostoru pro občany z třetích zemí (Blum Le Coat, Eberhard, 2014: 46 - 47): urychlení procedury u zjevně nedůvodných žádostí o azyl (1992); omezení možnosti sloučení rodiny (1993); omezení přístupu pracovníků ze třetích zemí na pracovní trh EU (préférence européenne à l'emploi, 1994); začlenění do dohody z Cotonou o partnerství se státy vafrické, karibské a tichomořské oblasti doložky o zpětném přijetí (clause de réadmission, 2000) př́slušníků těchto států nepovolaně pobývajících na území EU; doložky o společné správě migračních toků a o povinném přijetí $\mathrm{v}$ př́ípadě nepovolené imigrace v dohodách o spolupráci s třetími zeměmi a boj proti nepovolené migraci, obecně již výše zmíněné readmisní smlouvy (accords de réadmission) jako nástroj řešení problému nelegální migrace (Evropská rada v Seville, 2002, Haagský program, 2004); sankce pro dopravce přepravující nepovolené migranty; směrnice o bezpečných tř̌etích zemích (2005), vysílání styčných úředníků pro přistěhovalectví a azyl (officier de liaison immigration et asyle) do třetích zemí pro posílení kontroly vnějších hranic $\mathrm{v}$ rámci agentury FRONTEX; to vše doplněné o různé nástroje pro vedení záznamů: databáze Eurodac shromažd'ující otisky prstů žadatelů o azyl (2000), vízový informační systém (système d'information sur les visas, VIS, 2004) a evropský 
systému kontroly hranic (système européen de surveillance des frontières, EUROSUR, 2008);

- rozhodnutí o vytvoření společného evropského azylového systému (régime d'asile européen commun, dokončen 2013) se zahrnutím Ženevské úmluvy o právním postavení uprchlíků, včetně Newyorského protokolu z roku 1967, čímž byla potvrzena zásada nenavracení do země, kde by žadateli o azyl hrozilo pronásledování (principe de non-refoulement); minimální standardy při určování statusu uprchlíka, maximální délku trvání řízení atd.

- zavedení modré karty EU (carte bleue européenne) upravující podmínky vstupu a pobytu vysoce kvalifikovaných migrantů.

Postupný obrovský nárůst žadatelů o azyl v zemích EU vedl k nutnosti harmonizace norem v oblasti nejen azylové, ale celkově imigrační politiky v Evropě. Jak z výše uvedeného výčtu hlavních opatření vyplývá, při vytváření zejména společné azylové politiky čelí Evropa dvěma protichůdným tlakům souvisejícím s humanitárními aspekty na jedné a bezpečnostními aspekty na druhé straně. Členské státy jsou vázány mezinárodními smlouvami vztahujícími se kuprchlíkům Ženevskou úmluvou o právním postavení uprchlíků z roku 1951 a dalšími mezinárodními smlouvami o ochraně lidských práv: úmluvami OSN či Evropskou úmluvou o ochraně lidských práv a svobod z roku 1950, ve kterých je zakotven zákaz mučení a nelidského zacházení a lze z nich přímo odvodit ochranu osob žádajících o azyl před vyhoštěním do zemí, ve kterých jim hrozí vážné nebezpečí pronásledování. Tento minimální standard převzaly jednotlivé státy do svých vnitrostátních právních rádů a přijaly zákony o azylu či o postavení uprchlíků. Na druhé straně nutí masivní př́liv žadatelů o azyl, postupná komunitarizace evropských azylových politik, obavy z terorismu i domácí tlak veřejného mínění nejen členské státy, ale i Brusel, aby zpř́ísňoval pravidla pro udílení azylu a externalizoval svou azylovou politiku, tj. převáděl svou zodpovědnost v této oblasti na třetí země. Na evropské i - jak uvidíme na případu Francie - na vnitrostátní úrovni se tedy mísí lidsko-právní prvky s prvky restriktivními.

Před hlubší analýzou francouzské přistěhovalecké politiky a zpơsobu, jakým Francie měnila svou koncepci vztahu k přistěhovalcům v závislosti na ekonomické situaci, ale i vzhledem k sociálním problémům, je ovšem zajímavé se podívat na způsob, jakým se bruselské instituce snaží čelit současnému hromadnému přílivu imigrantů z třetích zemí, ale i na statistické údaje ukazující, které země jsou tímto prŕlivem především dotčeny. Pomohou nám tak ukázat, zda jsou obavy kritiků současné evropské přistěhovalecké politiky oprávněné či nikoliv.

\subsection{Současný vývoj}

V květnu 2015 se Evropská komise v kontextu masivních př́livů uprchlíků ve službách převaděčů $\mathrm{v}$ oblasti Středozemí, často s tragickým koncem, rozhodla k posílení své migrační politiky. Kromě posílení ochrany svých vnějších hranic v rámci Frontexu a vojenských zásahů proti síti převaděčů (zničení jejich lodí) navrhla také systém kvót pro každou členskou zemi pro vyváženější přerozdělení žadatelů o azyl, kteří jsou již na evropském kontinentě. $\mathrm{K}$ tomu chce využít prostředku předběžného opatření, které může přijmout ,ve stavu nouze v důsledku náhlého př́ilivu státních př́slušníků třetích zemí" na základě čl. 63 odst. 3 Lisabonské smlouvy. Počet imigrantů přidělený každé zemi by byl kalkulován na základě čtyř kritérií: HDP, míra nezaměstnanosti, počet obyvatel a počet již registrovaných žádostí o azyl v dané zemi. Rozhodnutí o přidělení či nepřidělení statusu uprchlíka nebo doplňkové ochrany by pak bylo na dané zemi, jako je tomu nyní. Vedle přerozdělení žadatelů o azyl již př́ítomných v Evropě (Itálii a Řecku) se zároveň jednalo o přijetí 24000 vysídlenců, kteři mají přiznán status uprchlíka OSN a jejichž rozdělení do 
jednotlivých států by probíhalo podle stejných kritérií. Zároveň by rozhodnutí o jejich ochraně opět bylo přijímáno v daných členských státech. Francii by tak naprríklad připadlo 2375 dalších žadatelů, což představuje 14 \% těchto vysídlenců a jen malou část z celkového počtu žadatelů o azyl ve Francii (v roce 2014 šlo o 63000 osob). Vedle i jiných návrhů Komise na řešení současné imigrační krize (společný evropský seznam bezpečných zemí původu a jeho rozšíření o další země pro zrychlení individuálních žádostí o azyl z těchto zemí, účinnější návratová politika, diplomatická řešení konfliktů v Sýrii a Iráku, boj proti převaděčům, fond na pomoc africkým zemím atd.) byl Rozhodnutím Rady EU ze září 2015 nově přijat provizorní mechanismus pro naléhavou relokaci dalších 120000 osob z Itálie a Recka s jednoznačnou potřebou mezinárodní ochrany (v 1. fázi 66000 osob, Mad'arsko účast na tomto mechanismu odmítlo).

Některé členské státy, především země střední a východní Evropy, se však vyjádřily proti této formě ,povinné solidarity“. Je třeba zdůraznit, že počty imigrantů, které by právě např́iklad země střední a východní Evropy měly přijmout, jsou velmi malé v porovnání $\mathrm{k}$ množství migrantů mírících $\mathrm{k}$ hranicím Unie. Podle International Organisation of Migration se přes Středozemní moře vydalo jen tento rok v období leden - srpen nejméně 350000 migrantů. Např́klad Estonsko mělo podle původního návrhu přijmout 738 žadatelů o azyl, přesto tato otázka podle velvyslance Estonska u EU vyvolává v zemi nejživější debatu o politice EU od přistoupení Estonska v roce $2004^{1}$. Nejvíce migrantů mělo podle rozhodnutí z května přijmout Německo (nejlidnatější země Unie s nejmenší nezaměstnaností) s 18,42 \%, následováno Francií $(14,17 \%)$ a Itálíí $(11,84 \%)$.

V kontextu tohoto masivního př́livu je zajímavé podívat se na některá statistická čísla z minulých let (Eurostat, 2015a). V roce 2014 se počet žadatelů o azyl v Evropské unii zvýšil o celých 44 \% (o 191000 osob více, na celkový počet 626000 žadatelů), nejvíce se zvýšil počet syrských žadatelů (123000 v r. 2014 oproti 50000 v r. 2013). Vyhověno bylo $185000 \mathrm{z}$ nich (přidělení statusu uprchlíka, doplňkové ochrany nebo práva pobytu $z$ humanitárních důvodů), $z$ více než jedné třetiny se jednalo o syrské občany. Mezi země, které vyhověly nejvíce žádostem, patří Švédsko $77 \%$, Itálie $59 \%$ a Německo $42 \%$. Pro srovnání, Mad’arsko, jako 5. země v počtu žádostí o azyl v Unii (před Velkou Británií) vyhověla jen 9 \% žádostí, Bulharsko oproti tomu $94 \%$ (Eurostat, 2015b).

Ukazuje se, že v roce 2014 nepatřila Francie mezi země nejvíce čelící náporu žadatelů: s 62800 žadateli, představujícími $10 \%$ z celkového počtu žadatelů je až na 4. místě za Německem (202 700, tedy $32 \%$ z celkového počtu žadatelů), Švédskem (81 200, 13 \%) a Itálií (64 600, 10 \%). Následuje Mad'arsko (42 800, 7 \%). Navíc je nutné vyzvednout, že zatímco počet žadatelů o azyl se v roce 2014 ve srovnání s r. 2013 více než zdvojnásobil - např. v Itálii (+143\%) a v Mad’arsku (+126 \%), či zažil velký nárůst (Německo - 60 \%, Śvédsko - $50 \%$ ), ve Francii se naopak snížil o $5 \%$.

Je třeba ovšem brát $\mathrm{v}$ úvahu poměr k celkovému počtu obyvatel - v této optice největší míru žadatelů přijalo Švédsko ( 8,4 žadatelů na 1000 obyvatel), daleko před Mad'arskem $(4,3)$ nebo Německem $(2,5)$. Nejméně žádostí o azyl v poměru k počtu obyvatel bylo naopak podáno právě v zemích střední a východní Evropy - ČR, Estonsko, Rumunsko, Slovensko $(0,1)$ či Portugalsku (0 na 1000 obyv.). Francie se s 1 žádostí na 1000 obyvatel také nachází pod průměrem EU $(1,2)$.

Francie ani země střední a východní Evropy nepatří mezi zóny nejvíce zasažené hromadným př́livem imigrantů z třetích zemí. Navíc i přes svůj tradiční obraz země ochraňující lidská práva není Francie v udělování statutu uprchlíka nejštědřejší: ze

${ }^{1}$ The Economist, „A walk down solidarity street“, 13/6/2015, s. 53.

11 
4 evropských zemí, které obdržely nejvíce žádostí o azyl (Německo, Švédsko, Itálie, Francie) Francie vyhověla nejméně žádostem v rozsudku prvního stupně (22\% z přijatých rozhodnutí, 14815 osob, oproti $42 \%$ pozitivním rozhodnutím v Německu, 59 \% v Itálii a 77 \% ve Švédsku) a ani v odvolacím řízení nejde o vysoká čísla (5 825 přijatých žádostí z 37085 odvolání, 16 \%). (Eurostat, 2015b)

Mnozí kritici azylového systému poukazují na to, že imigranti z ekonomických důvodů využívají procedury žádosti o azyl, aby se během čekání na vyřízení své žádosti usadili ve Francii, kde i tajně zůstanou po jejím zamítnutí s nadějí, že po pěti letech budou moci regularizovat svou situaci. Statistiky však ukazují, že nejvíce žadatelů o azyl ve Francii pocházelo v roce 2014 převážně z válečných oblastí nebo zemí, kde jim hrozilo pronásledování: z Demokratické republiky Kongo (5493 žádostí), Ruska (4206), Bangladéše (3809) a Sýrie (3154). Azyl byl pak poskytnut také nejčastěji Syřanům (1467 přijatých žádostí) a Rusům (1199) (podle zprávy o činnosti OFPRA, Le Monde, 2015a).

I přes současný obrovský př́liv imigrantů je třeba také poukázat na to, že se ve Francii jedná o jednu $\mathrm{z}$ dalších imigračních vln, které se $\mathrm{v}$ historii pravidelně opakovaly a dosáhly vrcholu na konci 80 . let 19. století (61 422 žádostí), v roce 2003 (59 770) a nyní prozatím v roce 2013 (60 230) (HCR de ONU, Le Monde, 2015b).

Podívejme se nyní, jak v závislosti na těchto vlnách i ekonomickém a sociálním kontextu Francie měnila svou přistěhovaleckou politiku a jak se měnil státem řízený vztah mezi imigranty a přijímací společností.

\section{Legislativa a migrační politiky ve Francii}

Než se budeme věnovat vývoji přistěhovalecké politiky ve Francii, je třeba upřesnit následující pojmy, které se vztahují ke stupni začlenění imigrantů do společnosti přijímací země (viz nap̌r. OIM, 2007; Lochak, 2006: 2). Tyto pojmy odrážejí různé politické př́stupy a v následující části uvidíme, jak se v historii imigrační politiky ve Francii promítaly do jednotlivých politických koncepcí a legislativních opatření.

Pojem asimilace (assimilation) odkazuje na úplné přijetí norem přijímací země ze strany imigrantů, kdy se jejich sociokulturní specifika spojená s jejich původní národní identitou projevují pouze v soukromém prostředí. Dochází k přijetí kulturních norem přijímací země až do postupné ztráty všech původních kulturních znaků, pokud jde o jazyk, zvyky, výkon náboženství a jiné. Imigrant se musí bezvýhradně přizpůsobit majoritní společnosti a musí přijmout za své hodnoty kultury a státu, do kterého imigroval.

Koncepce začlenění (insertion) je naopak nejméně důrazná: cizinec (imigrant) je zde sice chápán jako nedílná součást přijímací země, ponechává si ovšem svou původní identitu, jeho kulturní specifika jsou uznána jako taková a nejsou považována za překážku jeho integrace do společnosti pod podmínkou respektování pravidel a hodnot přijímací země. Jde o minimalistický přístup v příjmu jednotlivců, kteří plánují návrat do své země (chápán jako jedno $\mathrm{z}$ možných vyústění imigrace): proto nejsou ani z jedné, ani z druhé strany záměrně potlačována pouta imigranta se zemí původu.

Integrace (intégration) je výrazem dynamiky dialogu mezi přijímací a přijímanou populací, v rámci které všechny složky uznávají, že jsou součástí celku, kdy přistoupení na pravidla fungování a hodnoty přijímací země, stejně jako respekt k jednotě a integritě společnosti jako celku nebrání udržování rozdílů mezi komunitami. Ve Francii volba tohoto termínu nakonec převážila, poté, co určitou 
dobu v 70. a 80. letech „,soutěžila“ s konceptem ,insertion“1, aby nakonec vznikl koncept ,intégration à la française“, ,intégration républicaine“ (Lochak, 2006: 3).

Francie nejdříve v letech 1880-1960, podobně jako Spojené státy a Austrálie, uplatňovala vůči svým imigrantům politiku asimilace: imigranti tedy měli individuálně splynout $\mathrm{v}$ již nastaveném politickém společenství, na jehož utváření se nijak nepodíleli, a nechat za dveřmi svá národní a kulturní specifika (De Wenden, 2009: 72; pro historii imigrace ve Francii viz také Amar, Milza, 1990; Milza, 1985; Khames, Paoletti, 1993; Pan Ke Shon, Verdugo, 2014; Noiriel, 1988 a 1996; De Wenden, 1999 a 2002; Weil, 2005 a 1994). Po několik dalších desetiletí byl potom takový koncept přijetí imigrantů ve Francii tabu, dnes však opět ožívá: staronový předseda Republikánů (Les Républicains, dříve Union pour un mouvement populaire), Nicolas Sarkozy znovu přivádí tento koncept k životu, zavrhuje nefunkční politický koncept integrace ve snaze potlačit současný výrazný vzestup extrémně pravicově Národní fronty (volající, mimo jiné, po „immigration zéro“ a zrušení „droit du sol“ ve Francii) a přivést na svou stranu nerozhodnuté pravicové voliče: mluví o nutnosti asimilace imigrantů $\mathrm{k}$,našim hodnotám, našemu způsobu života“ a o islámu ve francouzském pojetí, který by přijal republikánské hodnoty (,un islam de France qui intègre les valeurs de la République“"2).

Kvůli zhoršující se ekonomické situaci a rozvoji masivní strukturální nezaměstnanosti začíná francouzská vláda v 70. letech 20. století systematicky bojovat proti príichodu nových imigračních pracovníkủ. Již v roce 1968, poprvé od konce 2. světové války, je oběžníkem ministerstva sociálních věcí zakázána legalizace zahraničních pracovníků, kteří na území vstoupili bez platného povolení k pobytu. Nejdůležitějším krokem bylo „pozastavení imigrace pracovníků“ v červenci 1976 (stejné rozhodnutí padlo v obtížném hospodářském kontextu i v Německu v r. 1973 a v Belgii v r. 1974), ve prospěch rodinné imigrace - sloučení rodiny (regroupement familial). Tato změna $\mathrm{v}$ orientaci imigrační politiky byla v letech 1977 - 1981 doplněna o pomoc (ve výši 10000 franků) při návratu. Ta byla původně zamýšlena především pro alžírské pracovníky, využili ji však především Portugalci a Španělé pro návrat do svých zemí (Blum Le Coat, Eberhard, 2014: 47). Pozastavení migrace pracovníků bylo původně zamýšleno jako krátkodobé opatření, který ovšem nakonec zůstalo nezpochybněno až do roku 2006, kdy byl schválen koncept selektivní imigrace - immigration choisie.

V rámci ,politique d'insertion des populations immigrées“ (dle slov tehdejšího státního tajemníka pro imigranty, Françoise Autaina, z r. 1982) je pomoc směřována místním samosprávám a upřednostňován je širší teritoriální přístup, nikoliv specifické zacílení na populaci imigrantů: vznik prioritních vzdělávacích oblastí (zone d'éducation prioritaire, ZEP), kde školská zařízení získávají více veřejných prostředků a pravomocí za účelem lepšího zvládnutí sociálních a vzdělávacích

${ }^{1}$ Nová imigrační politika představená státním tajemníkem pro imigrační pracovníky Paulem Dijoudem v roce 1976 používá termín ,insertion“ a levicoví politici ho budou upřednostňovat i v 80. letech vzhledem $\mathrm{k}$ ochotě uznat právo na jinakost imigračních pracovníků, kteří přinesli do Francie pracovní sílu (ještě v roce 1988 se zpráva Commissariat au plan (úřad pro plánování) nazývá „Immigration, le devoir d'insertion“, zdůrazňující respekt vůči druhému a nezávislost jednotlivých komponent). Na druhé straně pravicoví politici již na konci 70. let minulého století začínají používat termín ,intégration“ jako přímou náhradu konceptu asimilace. (Lochak, 2006: 4).

${ }^{2}$ Viz např. Le Monde z 20/3/2015 nebo Le Figaro ze 07/02/2015: „Nicolas Sarkozy relance le débat sur l'islam de France“. 
problémů; politika sociálního rozvoje čtvrtí (développement social des quartiers, DSQ) pro boj proti ghetoizaci znevýhodněných čtvrtí, zahrnující programy na podporu populace imigrantů; smlouvy mezi státem a malými a středně velkými městy o ekonomickém rozvoji a službách obyvatelům voblasti bydlení, sociálního a profesního začlenění (contrats d'agglomération). Zároveň je zákonem z r. 1981 cizincům umožněno svobodně se sdružovat, což vede k podpoře komunit, sdružování imigrantů i jejich dětí.

Opakované nepokoje na předměstích velkých měst, nárůst preferencí Národní Fronty (v parlamentních volbách v roce 1986, ve kterých se výjimečně uplatňoval systém poměrného zastoupení, získala strana 35 poslaneckých křesel), aféra se zákazem nošení šátku třem muslimským žákyním na střední škole v departementu Oise, která odstartovala ve Francii v roce 1989 jednu z prvních debat o principu laïcité (sekulární povaha státu) v opozici k respektu kulturní odlišnosti - to vše nutí tehdejší politickou elitu k reorientaci imigrační politiky. Dochází k institucionalizaci politického imigračního diskursu: vzniká Comité interministériel à l'intégration (1985), Secrétaire général à l'intégration (1985), později i Haut Conseil à l'intégration (1989) pro koordinaci politiky integrace zahraniční populace, kdy se pojem integrace stává oficiálně používaným v souvislosti s imigranty dlouhodobě usazenými na území Francie, u kterých se nepředpokládá návrat (v roce 1984 je také vytvořena desetiletá pobytová karta pro dlouhodobé rezidenty se symbolickým významem: imigranti již nejsou považováni za jednu ze složek dočasné pracovní síly, ale jako stálý prvek francouzské společnosti). Právo na odlišnost v rámci konceptu „,insertion“ tak přenechává místo náročnější koncepci většího začlenění imigrantů do francouzské společnosti a povinnosti respektovat její tradiční hodnoty (Lochak, 2006: 5). Zároveň pokračuje politika zacílená na rozvoj měst (politique de la Ville), v rámci níž je např. v 60 městech vyvíjena snaha o úplnou integraci a potlačení ohnisek sociálního vyloučení pomocí školní podpory dětí, administrativní, právní i jazykové pomoci pro nově příchozí, komunitních služeb atd. Tato městská politika opět není namířena výhradně na populaci imigrantů, přesto právě především jejím prostřednictvím může vláda uskutečňovat svou imigrační politiku: např. v r. 1998 je integrace přistěhovalců podle Comité interministériel à la Ville jednou z hlavních vládních priorit, která by se měla promítat do všech smluv s městy v období 2000-2006. Jednou z hlavních os přistěhovalecké politiky je také boj s diskriminací (rasovou, př́stupu na trh práce atd.), kdy již není cíleno prioritně na cizince, ale na francouzské občany - imigranty druhé, či dokonce třetí generace (vznik commissions départementales d'accès à la citoyenneté - CODAC v r. 2000, přijetí zákona o diskriminacích v r. 2001 a vznik Vysokého úřadu pro boj s diskriminacemi a pro rovné prŕležitosti v r. 2001 - Haute autorité de lutte contre les discriminations et pour l'égalité, HALDE). V tomto kontextu se také ve Francii diskutovalo o umožnění sběru statistických dat o jednotlivých etnikách př́tomných ve Francii v rámci zákona předloženého ministrem vnitra Bricem Hortefeuxem v r. 2007, tento návrh byl ale ústavním soudem později zrušen z důvodu nesouladu s Ústavou (De Wenden, 2009: 74).

Pro druhou polovinu let 2000-2010 je charakteristická především reorientace přistěhovalecké politiky od pasivně přijímané imigrace (immigration „subie“, do které tehdejší ministr vnitra Nicolas Sarkozy zahrnuje nejen nelegální imigraci, ale i imigraci v rámci sloučení rodin a žadatele o azyl) $\mathrm{k}$ imigraci selektivní (immigration „choisie“), posvěcené zákony „Sarkozy“ a „Hortefeux“ z let 2006 a 2007. Demografický a ekonomický vývoj prrinutil vládu, aby revidovala přistěhovaleckou politiku nasměrovanou od roku 1974 na slučování rodin, směrem k podpoře příchodu pracovníků vybraných kategorií. Byly tak ustanoveny seznamy profesí, pro něž jsou vystavována dočasná povolení k pobytu, aniž by podnikům nabírajícím zahraniční pracovníky byla ukládána povinnost hledat nejprve na francouzském trhu práce: 
v současnosti jde o seznam 30 profesí, v rámci kterých mohou být přijímáni státní př́slušníci třetích zemí. Je také ustanoveno mnoho různých nových dočasných povolení k pobytu (zákonem z roku 2006 vzniká pobytová karta „sezónní pracovník“ - carte de séjour „travailleur saisonnier“, pro pracovní pobyt v zemědělství a hoteliérství nepřesahující 6 měsíců; pobytová karta „salarié en mission“ pro pracovníky detašované v rámci zahraniční firmy dočasně do Francie, pobytová karta „compétences et talents“ týkající se cizinců, kteří chtějí na základě svého osobního projektu přispět k „ekonomickému rozvoji Francie i země svého původu“ nebo k, ,intelektuálnímu, vědeckému, kulturnímu, humanitárnímu nebo sportovnímu rozmachu“ Francie či své země.

Na základě předběžných dílčích návrhů je pak ve Francii přijato zákonem o sociální soudržnosti z 18. ledna 2005 opatření ve formě ,smlouvy o prijetí a integraci“ (contrat d'accueil et d'intégration), kterou od roku 2007 musí podepsat každý nově příchozí imigrant do Francie. Cizinci se tak zavazují k tomu, že získají $\mathrm{v}$ rámci jednodenního školení občanské vzdělání o francouzských institucích a hodnotách francouzské republiky (především o principu sekulární povahy státu a rovnosti mužů a žen, viz také Alaoui, 2012) a absolvují semináŕe o organizaci francouzské společnosti (zdravotnictví, školství atd.), v př́ípadě potřeby i jazykové vzdělání. Podpis a dodržení povinností plynoucích z této smlouvy patří mezi hlavní kritéria potvrzující integraci dané osoby do francouzské společnosti a jsou podmínkou pro obdržení dlouhodobého povolení k pobytu (10 let). Tato smlouva je tak vyústěním politických snah o selektivní imigraci, kdy jsou propojena sémantická pole pojmů „integrace“ a „Republiky“ (ve smlouvě je kladen důraz na „philosophie républicaine“, „régime républicain“, „ambition républicaine“ - vztahující se k rovnému zacházení, „droit politique républicain de la citoyenneté“, „loi commune républicaine“): príijetí republikánských hodnot a zásad je hlavním předpokladem úspěšné integrace (Lochak, 2006: 6). Toto opatření je od roku 2007 doplněno o verzi pro imigraci v rámci sloučení rodiny, na základě které rodiče musí absolvovat školení o právech a povinnostech rodičů ve Francii a dodržet povinnou školní docházku pro jejich děti ve věku 6-16 let.

Souběžně s vůlí úspěšně integrovat přistěhovalce do francouzské společnosti spadá pod francouzskou imigrační politiku i soustavná snaha o regulaci migračních toků, a to i v závislosti na postupné komunitarizaci imigrační politiky. Jde především o regulaci neregulérní migrace: již od svého př́chodu na ministerstvo vnitra $\mathrm{v}$ roce 2002 udělal Nicolas Sarkozy z vyhoštění osob neregulérně pobývajících na území Francie svou prioritu: roční kvantifikované cíle (např. cíl 23000 vyhoštěných osob v roce 2005; v roce 2011 už bylo vyhoštěno 33000 ), výrazné navýšení rozpočtu v této oblasti, renovace a výstavba nových zajišstovacích zařízení (CPA, viz níže). Tuto snahu lze vypozorovat ve všech hlavních obdobích od roku 1975, vyjmenujme jen několik nejvýznamnějších zákonů (Blum Le Coat, Eberhard, 2014):

- „loi Bonnet“ v r. 1980 - masivní navracení migrantů pobývajících neregulérně na francouzském území, zastavené procedurou výjimečné regularizace (régularisation exceptionnelle) neregulérních přistěhovalců v r. 1982 a ochráněním zejména cizinců, kteří prokáží rodinné svazky s Francouzi, před nutností ukončit svůj pobyt v zemi; vyvážené i dalšími výhodami pro imigranty (rovnost mezi francouzskými a zahraničními pracovníky v podniku, vytvoření desetileté pobytové karty rezidenta zákonem ze 17. července 1984);

- od roku 1984 jsou otvírána zajištovací zařízení (centres de rétention administrative, CRA), kde jsou zadrženi cizinci, kterým byl zakázán pobyt na území Francie a kteří nemohou okamžitě opustit Francii (zákonná délka zadržení cizinců v CRA se postupně prodloužila ze 7 dnů v roce 1981 na 45 v roce 2011); čekací zóny (zones d'attente) na letištích a v přistavech pro cizince, kteří nemají povolení 
vstoupit na území Francie nebo tam pobývají po dobu nezbytně nutnou (maximálně 8 dnů) během řízení o jejich žádosti o azyl, fungují od roku 1992;

- „loi Pasqua“ v r. 1986 - opětovné omezení práva na obdržení karty rezidenta a omezení ochrany před vyhoštěním ze země (éloignement), návrh na zrušení automatického získání francouzského občanství v 18 letech pro cizince narozené ve Francii nebyl nakonec prijat;

- druhý zákon „loi Pasqua“ z r. 1993 - zrušení sociálního zabezpečení pro cizince neregulérně pobývající na francouzském území, zrušení karty pro dlouhodobé rezidenty pro polygamní občany, především zpřísnění imigrační politiky v rámci slučování rodin (podmínky na finanční prostředky) a uplatňování sankcí pro ty, jejichž rodinní př́slušníci pobývají na území neregulérně, větší kontrola smíšených manželství (účelové sňatky), rozšiřrení možností odebrání a neobnovení pobytových karet; tato opatření jsou potvrzena zákonem z r. 1998 („loi Chévènement“), který systematizuje dočasná povolení k pobytu na úkor dlouhodobých pobytových karet, včetně cizinců, kteří prokázali osobní a rodinné svazky s Francií a které ochraňovala legislativa z r. 1984;

- oba zákony „lois Sarkozy“ z roku 2003 a 2006 pokračují v této logice omezování př́ístupu ke kartě rezidenta (právo na ni ztrácejí např. rodinní př́íslušníci a rodiče francouzských dětí, manželé a manželky Francouzů i cizinci pobývající na území Francie pravidelně po dobu 10 let), dočasný pobyt je systematicky prodlužován tak dlouho, dokud cizinec neprokáže dostatečnou integraci do francouzské společnosti (integrace jako př́kaz pro nově příchozí, viz výše „contrat d'accueil et d'intégration), je vytvořen systém snímání otisků prstů žadatelů o vízum, ztížena procedura slučování rodin;

- „loi Hortefeux“ z roku 2007 povyšuje účelové sňatky na trestný čin s hrozbou až 5 let odnětí svobody; karta rezidenta může být navíc manželovi či manželce francouzského občana odňata, pokud do 4 let od svatby dojde k rozvodu; rodinní příslušníci musí před příchodem do Francie ve své zemi složit zkoušku prokazující jazykové znalosti i znalosti hodnot francouzské republiky;

- „loi Besson“ z r. 2011 předpokládá posílení administrativních, finančních a trestních sankcí vůči osobám, které vědomě zaměstnávají cizince bez povolení k pobytu; převádí také do vnitrostátního práva evropskou směrnici o „navracení“ migrantů (directive „retour“), kdy je rozhodnutí o vyhoštění doplněno o zákaz návratu na francouzské území na dobu až pěti let; opět se prohlubuje kontrola účelných manželství, a to penalizací tzv. mariages gris, tj. v případech, kdy cizinec účelově citově podvedl svého francouzského partnera / partnerku, když s ním vstoupil do manželského svazku „,bez manželských úmyslư“.

Tato restriktivní legislativa s cílem omezit migrační toky a především neregulérní migraci je důsledkem nových výzev po pádu berlínské zdi, četných politických krizí v zemích historicky spjatých s Francií, postupné komunitarizace evropské azylové politiky, narůstajícího tlaku a popularity extrémně pravicových stran i vzrůstajících obav z islámského radikalismu (De Wenden, 2009: 70).

V současnosti ve Francii i nadále převažuje koncept ,immigration choisie“: pro usnadnění mobility talentů a zatraktivnění Francie je navrženo až 4leté povolení k pobytu pro investory, vědce, umělce a kvalifikované pracovníky (,passeport talents"). Z pohledu azylové politiky odpověděla francouzská vláda na současnou evropskou imigrační krizi zatím sérií opatření kombinujících humanitární přístup s restriktivním, bezpečnostním: na jedné straně byla ubytovací kapacita v prijímacích centrech pro žadatele o azyl a uprchlíky v červnu 2015 navýšena o dodatečných 10500 míst, na straně druhé si přeje vláda dvakrát zvýšit počet dobrovolných návratů ekonomických migrantů, evakuaci zdravotně závadných tábořišt' (např. u stanice metra La Chapelle v Paříži), vytvoření zatím blíže neurčených „pôles 
d'éloignement" posilujících proces vyhoštování imigrantů, finanční podporu pro návrat, zpř́ísnění opatření pro boj s neregulérní migrací atd. Reforma budoucí azylové politiky zahrnuje především opatření na zkrácení doby vyř́zení žádosti o azyl (ze současných 19 měsíců v průměru od doby podání žádosti až po odvolací ř́zení by se vláda chtěla posunout $\mathrm{k} 9$ měsícům) či řízené ubytování žadatelů o azyl po celé Francii pro odlehčení nejzatíženějším prefekturám v Paříži a regionu Rhônes-Alpes. Zároveň musí Francie do konce roku 2015 převést do vnitrostátního práva evropské směrnice „azylového balíčku“ v rámci společného evropského azylového systému.

\section{Závěr}

Naším cílem bylo představit hlavní pojmy spojené s tematikou imigrace: v první části jsme vymezili pojmy spojené se statusem migranta, přičemž jsme se u statusu „,̌zadatele o azyl“ věnovali v širši míře i proceduře udělení statusu uprchlíka ve Francii, tak jak je aktuálně v této zemi platná: podmínkám jeho udělení i aktérům, kteří $\mathrm{v}$ tomto rámci zasahují. Zároveň jsme představili typologii migrace $\mathrm{z}$ hlediska délky pobytu i její povahy. Naší motivací bylo tak představit základní lexikum spojené s touto vysoce aktuální tematikou imigrace pro lepší orientaci v současně vedených diskusích na toto téma.

V druhé části jsme pak - stále s cílem přinést definici hlavních pojmů, konceptů a politik - zaměřili na migrační politiku vedenou na evropské úrovni: vzhledem ke zrušení vnitřních hranic $\mathrm{vEU}$ na základě schengenských dohod nelze již problematiku imigrace, narůstajícího počtu pristěhovalců a společenské soudržnosti nahližet pouze z perspektivy jednotlivých samostatných států, ale celého evropského společenství. Díky postupující evropské integraci a principu volného pohybu osob na území EU již za migranty nejsou považováni př́slušníci EU pohybující se v rámci evropského prostoru, ale státní př́slušníci třetích zemí, kteří opět neprricházejí do jediného státu, ale vstupují do celé Unie. Reálné hranice uvnitř Evropy tedy neexistují a vše se nadále odehrává na hranicích vnějších. Proto EU vytváŕí společná pravidla především týkající se kontrol na hranicích a azylového řízení, aby ovlivnila a usměrnila př́liv osob ze třetích zemí a jejich pohyb na svém území.

Přestože Lisabonská smlouva umožňuje ovlivnit i redistribuci žadatelů o azyl mezi členskými zeměmi v nouzových situacích, nedávná jednání na evropské úrovni ukázala, do jaké míry je řízená solidarita velice citlivým politickým tématem. V přistěhovalecké politice mají nejširší pole působnosti členské státy, na evropské úrovni jsou uplatňovány právní předpisy pouze pro jednotlivá odvětví v závislosti na kategorii migrantů, např. zavedení modré karty pro vysoce kvalifikované pracovníky. Imigrační politiku každého státu neovlivňují dnes jen společná evropská pravidla, ale i migrační toky vyplývající z jeho regionálního sousedství a historických svazků s tou či onou oblastí ve světě, demografický vývoj, možnosti trhu práce a v neposlední řadě - a dnes by se dalo říci především - i bezpečnostní otázky, veřejné mínění a obavy z islámského fundamentalismu. Proto jsme se snažili jak na celoevropské (druhá část), tak na vnitrostátní francouzské (trretí část) úrovni ukázat tuto dynamiku mezi humanitárním př́stupem $\mathrm{v}$ př́stupu $\mathrm{k}$ žadatelům $\mathrm{o}$ azyl na jedné straně a sekuritářským přístupem a zpřísňováním podmínek pro vstup, včetně boje s neregulérní migrací, na straně druhé.

Ve třetí části jsme se pak snažili o představení pojmů a koncepcí charakterizujících vztah mezi migrantem a přjímací zemí (Francií) a o historický přehled migračních politik od zlomu nastalého v 70. letech po současnost. Tento vývoj v jednotlivých koncepcích (assimilation - insertion - intégration - dnes opět assimilation?) a restriktivní opatření (vízová, azylová politika, systematizace dočasných povolení k pobytu, nutnost prokázat přijetí „republikánských hodnot“" v rámci „contrat d'accueil et d'intégration“ pro obdržení dlouhodobého povolení k pobytu, koncept selektivní imigrace, v poslední době i tendence omezit 
„droit du sol“ dle návrhů Nicolase Sarkozyho) jsou odrazem právě výše zmíněné dynamiky.

Hloubková analýza pojmů spojených s fenoménem migrace na obecné úrovni (status migranta, aktéry a motivy žádosti o azyl ve Francii, typologie imigrace) i na úrovni evropské (hlavní milníky vývoje společné imigrační politiky) a francouzské (vývoj politických konceptů odrážejících vztah mezi osobou migranta a prrijímací zemí) nám nyní umožňuje prripojit francouzsko-český terminologický přehled $\mathrm{s}$ tematikou azylu a migrace $\mathrm{s}$ nejčastěji vyskytovanými pojmy v této oblasti. Pro přehlednost a lepší orientaci jsme se rozhodli pro formu tematického glosář a rozdělili lexikum do podsekcí: lexikum spojené s jednotlivými statusy migranta, s procedurou žádosti o azyl, politickými koncepty, nejčastějšími doklady a typy povolení k pobytu, názvy francouzských i evropských / mezinárodních agentur, institucí, úřadů spojených $\mathrm{s}$ tematickou migrace. Čerpali jsme nejen $\mathrm{z}$ francouzského tisku, ale i v následujících databázích rekapitulujících ofíciální francouzské i české termíny v této oblasti: portál EU o imigraci (Commission européenne, 2015), informační portál francouzské státní správy (VIE PUBLIQUE, 2015), glosáŕ Mezinárodní organizace pro migraci (OIM, 2015) a v neposlední řadě i portál českého Ministerstva vnitra (Ministerstvo vnitra, 2015).

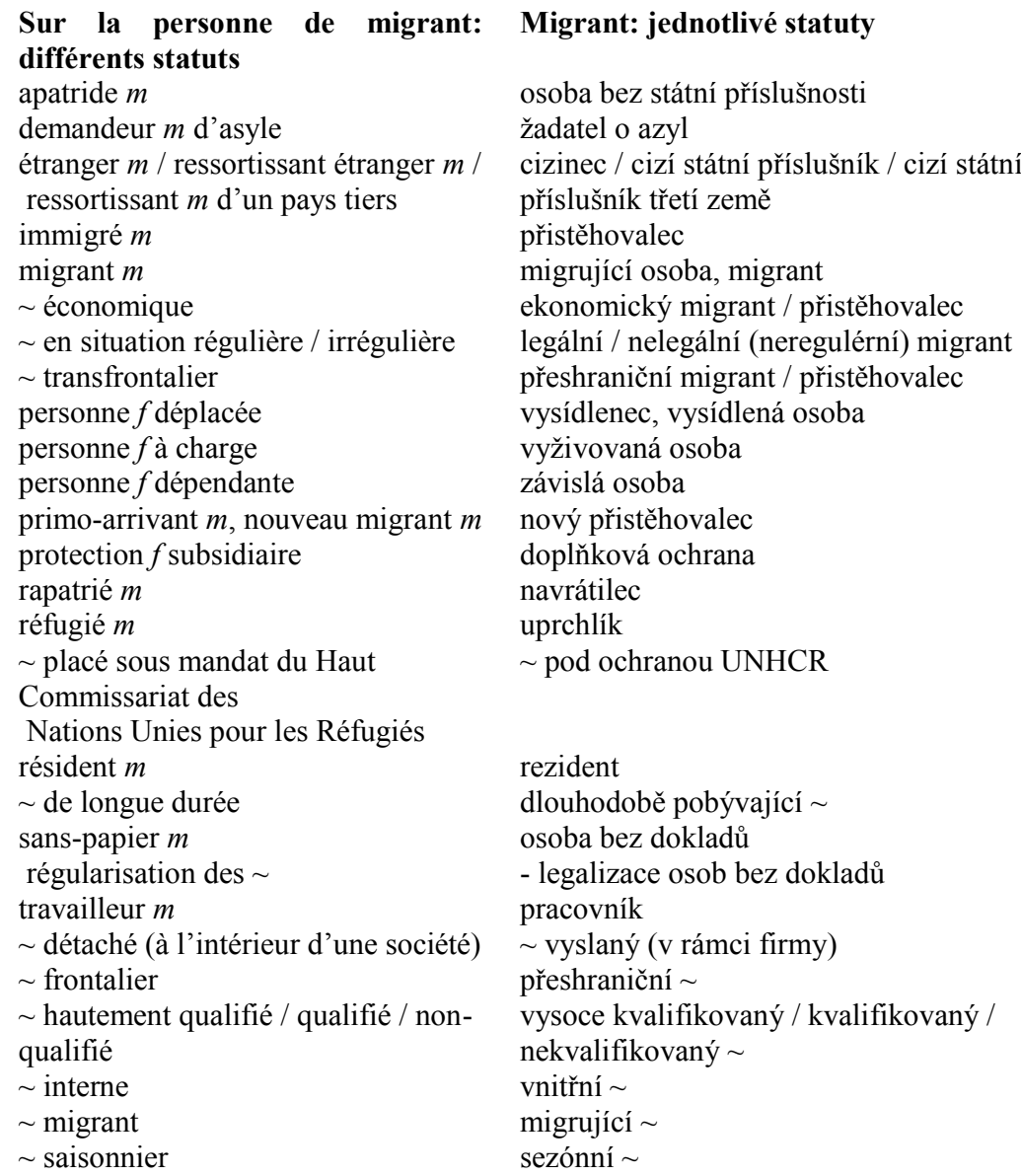


$\sim$ temporaire

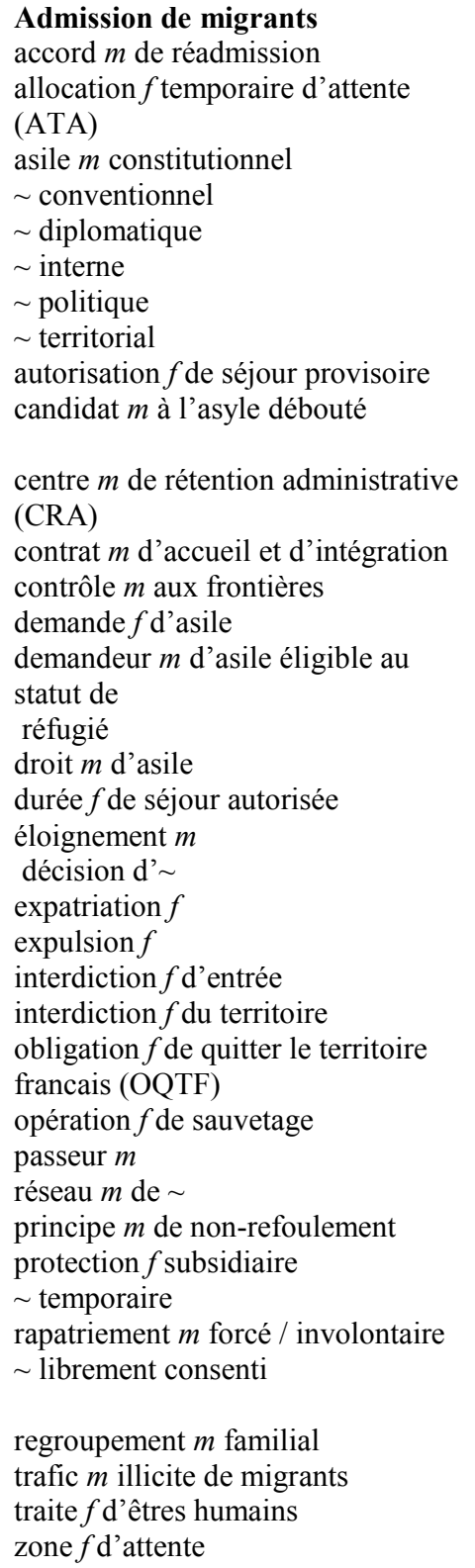

\section{Concepts politiques et sociaux /}

\section{Divers}

afflux $m$ massif de migrants attribution $f x x$ acquisition $f$ de nationalité

française dočasný

\section{Přijímání migrantů}

readmisní dohoda

dočasný čekací prríspěvek

ústavní azyl

konvenční

diplomatický

vnitřní

politický

územní

dočasné povolení k pobytu

uchazeč o azyl, jehož žádost byla

zamítnuta

zajišt’ovací zařízení

smlouva o přijetí a integraci

kontrola na hranicích

žádost o azyl

žadatel o azyl, který má nárok na

postavení uprchlíka

azylové právo

povolená délka pobytu

vyhoštění

rozhodnutí o vyhoštění

vypovězení z vlasti

vyhoštění

odepření vstupu

zákaz pobytu na území

povinnost opustit francouzské území

záchranná akce

prevaděč

sít' př̀vaděčů

zásada nenavracení

doplňková ochrana

dočasná ochrana

nucené / nedobrovolné navracení /

repatriace

dobrovolné navracení / repatriace

sloučení rodin

pašování přistěhovalců

obchodování s lidmi

čekací zóna

Politické a sociální koncepty / Různé

hromadný př́liv migrantů

přidělení francouzské národnosti (při

narození) xx nabytí francouzské

národnosti (později než při narození ) 
conditions $f p l$ d'admission

$\sim$ d'entrée

$\sim$ de séjour

discrimination $f$ raciale

droit $m$ du sang

$\sim$ du sol

Etat $m$ tampon

flux $m p l$ d'immigration

$\sim$ migratoires

frontière $f$ extérieure de l'UE

$\sim$ terrestre $=$ verte

$\sim$ maritime $=$ bleue

fuite $f$ des cerveaux

laïcité $f$

liberté $f$ de circulation de personnes

migration

$\sim$ de masse

$\sim$ de travail / professionnelle

$\sim$ économique

$\sim$ en chaîne

$\sim$ interne / internationale

$\sim$ familiale

$\sim$ pendulaire

$\sim$ politique

mobilité $f$ des étudiants / des jeunes

actifs / des

chercheurs

naturalisation $f$

pays $m$

$\sim$ d'accueil

$\sim$ de destination

$\sim$ d'origine

$\sim$ d'origine sûr

$\sim$ de résidence habituelle

$\sim$ de transit

$\sim$ tiers / tiers sûr

politique $f$

$\sim$ d'assimilation des immigrés

$\sim$ d'insertion des immigrés

$\sim$ d'intégration des immigrés

politique $f$ du retour

préférence $f$ communautaire

quota $m$ migratoire

route $f$ migratoire

solde $m$ migratoire

travail $m$ clandestin podmínky přijímání

podmínky vstupu

podmínky pobytu

rasová diskriminace

ius sanguinis (dítě nabývá státní

občanství toho státu, jehož státním

občanem je alespoň jeden $\mathrm{z}$ rodičů)

ius soli (dítě nabývá státní občanství

toho státu, na jehož území se narodilo)

nárazníkový stát

imigrační toky

migrační toky

vnější hranice EU

pozemní hranice $=$ zelená hranice

mořská hranice $=$ modrá hranice

únik inteligence

sekulární povaha státu

volný pohyb osob

migrace

hromadná

pracovní / profesní

ekonomická

řetězová

$\sim$ v rámci státu / mezinárodní

rodinná

kyvadlová

politická $\sim / \sim$ z politických důvodů

mobilita studentů / mladých pracovních

sil /

vědců

udělení státní příslušnosti

přijímací země

země určení

země původu

bezpečná země původu

země obvyklého bydliště

tranzitní země

třetí země / bezpečná třetí země

politika

$\sim$ asimilace imigrantů

$\sim$ začlenění imigrantı̊

$\sim$ integrace imigrantů

návratová politika

upřednostňování pracovníků členských

států

migrační kvóta

migrační trasa

migrační saldo

nelegální práce 


\author{
Documents \\ autorisation $f$ provisoire de séjour \\ carte $f$ de séjour temporaire \\ carte $f$ de résident \\ certificat $m$ de naissance \\ certificat $m$ de résidence \\ document $m$ d'identité / de voyage \\ frauduleux \\ empreintes $f p l$ digitales \\ passeport $m$ biométrique \\ permis $m$ de travail \\ titre $m$ / permis $m$ de séjour \\ délivrer un \\ visa $m$ de courte / longue durée
}

\section{Politique française et européenne relative à l'immigration : institutions, accords et autres}

accords $m p l$ de Dublin accords $m p l$ de Schengen Agence nationale d'accueil des étrangers et des migrations (ANAEM)

Association européenne de libreéchange (AELE)

centre d'accueil des demandeurs d'asile (CADA)

Code de l'entrée et du séjour des Etrangers et du Droit d'Asile (CESEDA)

Convention européenne de sauvegarde des droits de l'homme et des libertés fondamentales Cour nationale du droit d'asile Espace Economique Européen (EEE) Eurodac

Fond européen pour les réfugiés Haut Commissariat des Nations Unies pour les Réfugiés (HCR) Haut Conseil à l'Intégration (H.C.I.) Office français de l'immigration et de l'intégration (OFFI)

Office français de protection des réfugiés et apatrides

Organisation internationale pour les migrations (OIM)

régime d'asile européen commun Système d'Informations Schengen
Dokumenty / doklady

dočasné povolení k pobytu ( $\mathrm{z}$ důvodu léčby, dobrovolnictví)

dočasná pobytová karta

karta rezidenta (dlouhodobě

pobývajícího)

rodný list

potvrzení o trvalém pobytu (pro alžírské občany)

falešný doklad totožnosti / cestovní

doklad

otisky prstů

biometrický pas

pracovní povolení

povolení $\mathrm{k}$ pobytu

vydat povolení k pobytu

krátkodobé / dlouhodobé vízum

\section{Francouzská a evropská imigrační politika: instituce, dohody a jiné}

Dublinské dohody

Schengenské dohody

Národní agentura pro prŕijem cizinců a migrací

Evropské sdružení volného obchodu (ESVO)

středisko přijetí pro žadatele o azyl

Zákon o vstupu a pobytu cizinců a právu na azyl

Evropská úmluva o ochraně lidských práv a základních svobod

Národní soud azylového práva

Evropský hospodářský prostor

Elektronická databáze otisků prstů

Evropský uprchlický fond

Vysoký komisař OSN pro uprchlíky

Vysoká rada pro integraci

Francouzský úřad pro přistěhovalectví a integraci

Francouzský úřad pro ochranu uprchlíků a osob bez státní příslušnosti

Mezinárodní organizace pro migraci

společný evropský azylový systém

Schengenský informační systém 


\section{Bibliograpic references}

ALAOUI, M. H. 2012. L'intégration sous condition: valeurs non négociables et égalité des sexes. In: Canadian Journal of Women and the Law, vol. 24, n. 1, pp. 114134.

AMAR, M., MILZA, P. 1990. L'immigration en France au XXe siècle. Paris: Armand Colin. ISBN 978-2200371906

BLUM LE COAT, J.-Y., EBERHARD, M. 2014. Les immigrés en France. Paris: La Documentation française. ISSN 1763-6191

BOSWELL, C. 2003. The „external dimension“ of EU immigration and asylum policy. In: International Affaires, vol. 79, n. 3, pp. 619-638. ISSN: 1468-2346

COMMISSION EUROPEENNE. 2015. Le Portail de l'UE sur l'immigration. [cit. 28.06.2015] Available online <http://ec.europa.eu/immigration/portail-de-lus-surlimmigration-accueil_fr>

CORNUAU, F., DŪNEZAT, X. L'immigration en France: concepts, contours et politiques. In: Espace populations sociétés, n. 2008/2, pp. 331 - 352. ISSN 2104 3752

DE WENDEN, C. W. 1999. L'immigration en Europe. Paris: La Documentation Française. ISBN 978 -211-0039-705

DE WENDEN, C. W. 2002. Ouverture et fermeture de la France aux étrangers. In: Vingtième siècle. Revue d'histoire, 2002/1, n. 73. ISBN 9782724629170

DE WENDEN, C. W. 2008. L'Europe, un continent d'immigration malgré lui. In: Strates, 2008, n. 15, pp. 59-71. ISSN 1777 - 5442

DE WENDEN, C. W. 2009. La globalisation humaine. Paris: PUF. ISBN 978-2-13055003-7

EUROSTAT. 2015a. Demandes d'asile dans 1'UE. [cit. 22.06.2015] Available online $<$ http://ec.europa.eu/eurostat/documents/2995521/6751788/3-20032015-BP-FR.pdf/ e7d92e5a-5c17-4329-8497-8e336c546cef>

EUROSTAT. 2015b. Décisions sur les demandes d'asile dans l'UE. [cit. 22.06.2015] Available online $<\mathrm{http} / /$ ec.europa.eu/eurostat/documents/2995521/6827386/312052015-AP-FR.pdf/925df8c7-ac90-42e9-a659-8b435311 fbe4>

FRANCE DIPLOMATIE. 2015. Nationalité française. [cit. 22.06.2015] Available online $<$ http://www.diplomatie.gouv.fr/fr/services-aux-citoyens/etat-civil-et-nationalite/nationalite-francaise/>

INSEE. 2015a. Définitions et méthodes. [cit. 22.06.2015] Available online $<$ http://www.insee.fr/fr/methodes/default.asp?page=definitions/etranger $>$

INSEE. 2015b. Etrangers - immigrés. [cit. 22.06.2015] Available online $<$ http://www.insee.fr/fr/themes/document.asp?reg_id=0\&ref_id=T15F037>

KABWE-SEGATTI, A. 2009. Dimension extérieure de la politique d'immigration de l'Union européenne. In: Hommes et migrations. 2009, n. 1279, pp: 140-153. ISSN $1142-852 \mathrm{X}$

KRULIC, J. 2003. La notion légale de réfugié et le droit d'asyle en France. In: Revue internationale et stratégique, vol. 2, n. 50, pp. 131-138. ISBN 9782130537823

LE MONDE. 2015a. Les demandeurs d'asile ont-ils un coût «exorbitant» pour la France? [cit. 25.06.2015] Available online <http://www.lemonde.fr/lesdecodeurs/article/2015/05/06/les-demandeurs-d-asile-ont-ils-un-cout-exorbitant-pourla-france_4628840_4355770.html>

LE MONDE. 2015b. Cinq questions sur le droit d'asile. [cit. 25.06.2015] Available online <http://www.lemonde.fr/les-decodeurs/article/2015/06/22/cinq-questions-surle-droit-d-asile_4659408_4355770.html>

LOCHAK, D. 2013. Qu'est-ce qu'un réfugié ? La construction politique d'une catégorie juridique. In: Pouvoirs : Revue d'Etudes constitutionnelles et politiques, n. 144, pp. 33-47. ISBN 978-2-02-109781-8 
LOCHAK, D. 2006. L'intégration comme injonction. Enjeux idéologiques et politiques liés à l'immigration. In: Cultures et Conflits. 2006/4, n. 64, pp. 131 - 147. ISSN 1157-996X

MILZA, P. 1985. Un siècle d'immigration étrangère en France. In: Vingtième siècle. Revue d'Histoire, n. 7, pp. 3-18. ISSN 02941759

MINISTERSTVO VNITRA. 2015. Terminologicky slovnik. [cit. 20.06.2015] Available online <http:/www.mvcr.cz/clanek/terminologicky-slovnik.aspx?q= Y2hudW09NA\%3d\%3d>

NOIRIEL, G. 1996. The French melting pot : immigration, citizenship, and national identity. Minneapolis: University of Minnesota Press. ISBN: 0816624194

NOIRIEL, G. 1988. Le creuset français. Histoire de l'immigration XIXe - XXe siècle. Paris : Seuil. ISBN 2-02-015393-9

OIM. 2015. Glossaire de la migration. [cit. 20.06.2015] Available online $<$ http://publications.iom.int/bookstore/free/IML_9_FR.pdf $>$

PAN KE SHON, J.-L., VERDUGO, G. 2014. Ségregation et incorporation des immigrés en France. Ampleur et intensité entre 1968 et 2007. In : Revue française de sociologie, vol. 55, n. 2, pp. 245-283. ISSN 00352969

PAOLETTI, F. 1993. Quelle immigration en France? Paris: Hatier. ISBN 10: 2218074397

TRIBALAT, M. 1992. (Sous la direction de) Cent ans d'immigration, étrangers d'hier, Français d'aujoud'hui. Paris: PUF / INED. ISBN 2-7332-0131-X

TRIBALAT, M. 2010. Les yeux grands fermés. L'immigration en France. Paris: Denoël. ISBN 978-2-20726177-4

VIE PUBLIQUE. 2015. Les mots de l'immigration, de l'intégration. [cit. 20.06.2015] Available online <http://www.vie-publique.fr/politiques-publiques/politique-immigration/glossaire-definitions/>

WEIL, P. 2005. La France et ses étrangers. L'aventure d'une politique de l'immigration 1938 - 1991. Paris: Folio. ISBN-13: 978-2070411955

WEIL, P. 1994. La politique de la France. In : Politique étrangère, vol. 59, n. 3, pp. 719-729. ISBN 2200906803

Words: 10829

Characters: 75420 (41, 9 standard pages)

Mgr. Kateřina Dvoŕáková, Ph.D.

Department of Romance Languages

Faculty of International Relations

University of Economics

Nám. W. Churchilla 4

13067 Praha 3

Czech Republic

katerina.dvorakova@vse.cz 